Original Article

\title{
Floral biology and breeding system of endangered species: Parmentiera cereifera Seem. (Bignoniaceae)
}

\author{
Janis Damaiyani \\ Purwodadi Botanic Garden - Research Center for Plant Conservation and Botanic Garden, Indonesian Institute of Sciences, Purwodadi, Pasuruan, 67613, \\ Indonesia
}

Abstract

Parmentiera cereifera Seem. is an endangered species in the family Bignoniaceae. Related to the conservation effort, information about the reproductive biology of this species is very limited. Based on that, the objectives of this study were to provide knowledge about the reproductive properties such as floral biology and breeding system of $P$. cereifera. The research was conducted at Purwodadi Botanic Garden, from October 2019 to February 2021. Several important aspects of reproductive biology, including flower biology, pollen viability and stigma receptivity, pollen morphology and breeding system were investigated. The viability was tested with TTC $(2,3,5$-triphenly tetrazolium chloride) and stigma reseptivity was tested with hydrogen peroxide. The breeding system was determined based on outcrossing index (OCI) using Cruden's method. The results showed that $P$. cereifera flower was monoecious, had morphological character that supported nocturnal pollination. Stigma and anthers spatially separated, but there was no temporal separation of stigma receptivity and anther dehiscence. Based on the flower biology, the pollen ornamentation (reticulate type), and the Out-Crossing Index $(\mathrm{OCI}=4)$, the breeding system was outcrossing but partially self-compatible, required pollinators (zoophily).

Keywords: Bignoniaceae, breeding system, floral biology, P. cereifera.

Received: 6 May 2020 Revised: 25 June 2021 Accepted: 26 June 2021

\section{Introduction}

Studies of the reproductive biology and breeding systems of plants, especially on endangered, rare or threatened plant species, are vital to successful conservation efforts (Barrios \& Koptur 2011; Gan et al. 2013; Dhouibi et al. 2021). The studies useful for understanding why they are endangered, rare or threatened (Navarro \& Guitia'n 2002; Al-Hawshabi et al. 2017). The information is crucial for predicting their survival capacity and may be useful for evaluating alternative in situ and ex situ management strategies (Navarro \& Guitia'n 2002; Gan et al. 2013). If a plant is self-incompatible, it must have access to pollen from a particular genetic individual in order to reproduce successfully. If pollinators are needed, protection must provide habitat for pollinators as well as plant populations large enough to allow for cross-pollination. As a result, knowledge of breeding systems is important in developing integrated management strategies (Linares \& Koptur 2010).

Parmentiera cereifera Seem. or the candle tree is a species of tree in the family Bignoniaceae. It is a commonly cultivated specimen in botanic gardens, including Purwodadi Botanic Garden. The International Union for Conservation of Nature Red List of Threatened Species categorizes $P$. cereifera Seem. as endangered species (IUCN 2021). Therefore conservation efforts are needed to preserve this species.

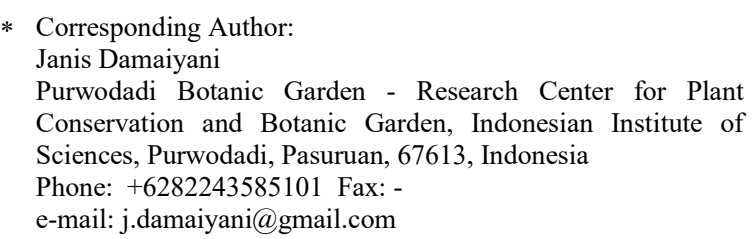

The tree is native to Panama and cultivated for ornamental uses in many tropical countries (Reyad-ulFerdous et al. 2012). Preliminary phytochemical investigation suggested the presence of flavonoids, saponins, tannins, triterpenoids and steroids. It has the ability as an antioxidant (Reyad-ul-Ferdous et al. 2012). The bark has the ability as an antimicrobial (Reyad-ulFerdous et al. 2015).

Related to the conservation effort, information about the reproductive biology of this species is very limited. Studies on reproductive ecology, reproductive biology, pollination, and breeding system from Bignoniaceae family have been conducted to Tabebuia chrysantha (Borrero 1972), Pachyptera hymenaea (Barrows 1977), Campsis radicans (Bertin 1982; Bertin 1985), Jacaranda caroba (Vieira et al. 1992), Pyrostegia venusta (GobattoRodrigues \& Stort 1992), Tabebuia caraiba (Gibbs \& Bianchi 1993), Tabebuia aurea and Tabebuia ochracea (Barros 2001). On the other hand, this information is needed in the conservation program for handling of endangered species. Based on that, the objectives of this study were to provide knowledge about the reproductive properties of $P$. cereifera, an endangered species. In this study, for advancements in breeding processes for $P$. cereifera, morphological characteristics and studies on floral biology of this species were conducted as well as pollen viability and stigma receptivity were studied.

\section{Methods}

\section{Study sites and plant materials}

The study was conducted from October 2019 to February 2021 at Purwodadi Botanic Garden Indonesian Institute of Sciences, which is located 300 meters above sea level and has temperatures ranging 
from $22^{\circ}$ to $32^{\circ} \mathrm{C}$. Plant material that was observed in this study was Parmentiera cereifera Seem. It has been planted at vak II.B.32 and XXII.I.4 (Fig. 1). The coordinates and the altitude of the sites are $-7^{\circ} 47^{\prime} 59^{\prime \prime} \mathrm{S}$ and $112^{\circ} 44^{\prime} 12^{\prime \prime} \mathrm{E}$.

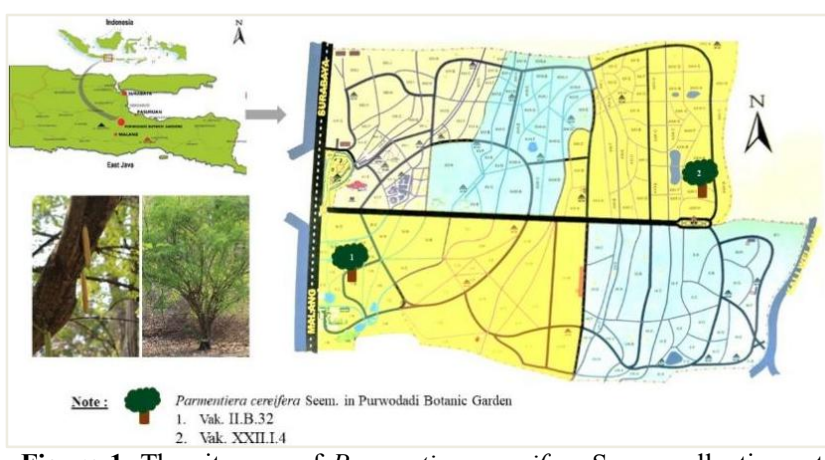

Figure 1. The site area of Parmentiera cereifera Seem. collentions at vak II.B.32 and XXII.I.4 of Purwodadi Botanic Garden

\section{Floral biology}

b.1. Observation on flower morphology and flowering stage development

Flowers of $P$. cereifera were collected on the day of anthesis for floral biological studies. Sepals, petals, stamens, and the gynoecium were all measured in length. The number of stamens and how they were arranged were also recorded. To examine the flowering stage development, observation was done for 6 months (October 2019-March 2020) on 20 flower samples starting from bud stage until pollination.

\section{b.2. Observation of pollen viability and stigma receptivity}

Pollen viability and stigma receptivity tests were performed on pollen grains and stigma from the D-1 and $\mathrm{D}$ anthesis stages. A coloring test with $1 \%$ TTC $(2,3,5$ Triphenyl tetrazolium chloride) was used to assess pollen viability (Demir et al. 2015; Soares et al. 2016; Rathod et al. 2018). This method was regarded as more efficient for it was quick and simple (Sulusoglu \& Cavusoglu 2014; Soares et al. 2016). Such pollen viability test using $1 \%$ TTC has ever been done on Bignoniaceae family like Campsis grandiflora (Chauhan \& Shakya 2014). Freshly collected pollens were separated from the anthers, and then transferred to microscope slides and stained with $1 \%$ TTC. After 1 hour, an observation was performed with Olympus CX31 microscope. Red pollen showed fertility/viability while those that were transparent showed sterility. The percentage of viability was calculated by using the following formula:

$$
\text { Pollen viability }(\%)=\frac{\text { Number of stained pollen grains }}{\text { Total number of pollen grains }} \times 100
$$

Stigmatic receptivity was determined by using hydrogen peroxide test (Makwana \& Akarsh 2017). Stigma on the day of anthesis stage and the one day before anthesis stage was put on a microscope slide set and then dropped by $6 \%$ hydrogen peroxide $\left(\mathrm{H}_{2} \mathrm{O}_{2}\right)$. The stigma was categorized as receptive if it reacted positively to the hydrogen peroxide solution, which was characterized by formation of air bubbles on its surface.

\section{b.3. Observation on pollen morphology}

Descriptive analysis was performed to the pollen morphology with reference to several palynology publication (Kapp 1969; Hesse et al. 2009; Halbritter et al. 2018). The parameters observed were the dispersal unit of pollen, polarity, length of polar axis $(\mathrm{P})$, length of equatorial axis $(\mathrm{E}), \mathrm{P} / \mathrm{E}$ ratio, shape of pollen, aperture type, and exine ornamentation.

\section{Breeding system of $\boldsymbol{P}$. cereifera : OCI (Out-Crossing Index) estimation}

The outcrossing index (OCI) was calculated using Cruden's method, as defined by Dafni (1992) (Hou et al. 2019). The OCI was determined from the fresh flowers, which is the sum of assigned values for three characteristics of the flower and floral behavior (Tab 1).

The total of the above three characteristics (diameter of the flower, temporal separation of anther dehiscence and stigma receptivity, and spatial relationship of stigma and anthers) is the OCI value which determines the breeding systems. The standards for judgment were as follows: when OCI was 0 point, the breeding system was cleistogamy; when OCI was 1 point, the breeding system was obligate autogamy; when OCI was 2 point, the breeding system was facultative autogamy; when OCI was 3 point, the breeding system was self-compatible and sometimes requires pollinators, and pollinators were needed sometimes; when OCI was 4 point, the breeding system was outcrossing but partially self-compatible, requires pollinators.

Table 1. Scoring standards of outcrossing index

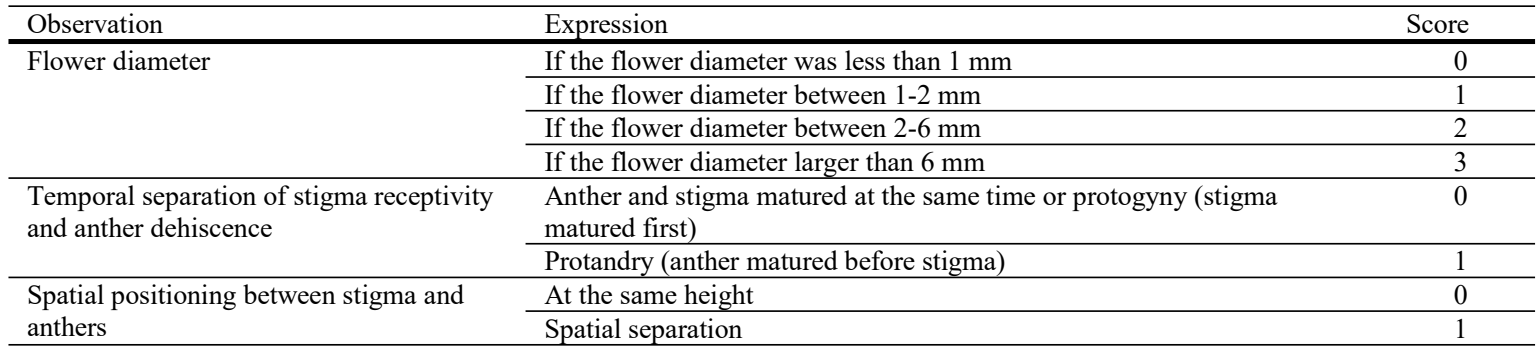




\section{Results}

Biological characteristics of $\boldsymbol{P}$. cereifera flower

a. Flower morphology and flowering stage development

The flower is the unit of sexual reproduction in angiosperms. Floral characteristics directly related to pollinator attraction are critical to mutualism maintenance, ensuring pollen grain transfer and thus reproductive success in outcrossing species (Souza et al. 2017). As a result, studies on reproductive ecology begin with an understanding of the flower's structure and functional aspects (Shivanna \& Tandon 2014). $P$. cereifera was categorized into polycarpic species and monoecious. Like the characteristics of the Bignoniaceae family in general, this species also has flowers that were shaped like trumpets (Fig. 2.a-c). The flowers solitary or in groups 2-4, directly on the trunk or the main branches. The calyx spathaceous and splits on one side (Fig. 2.a). The corolla were campanulate with white-greenish in color, with 5 curved lobes with wavy margins (Fig. 2.d). The androecium consisted of 4 epipetalous stamens, didynamous with 1 staminode (Fig. 2.e). The gynoecium greenish in color, consisted of 1 bilobed stigma, 1 long style, and superior ovary (Fig. 2.e). A detailed size of $P$. cereifera flower parts showed in Table 2.

Table 2. $P$. cereifera floral parts size

\begin{tabular}{lll}
\hline Period & Floral parts & Size \\
\hline D-2 anthesis (Figure 2.f) & Pedicellus & $\pm 1,5 \mathrm{~cm}$ \\
\cline { 2 - 3 } & Bud & $\pm 2 \mathrm{~cm}$ \\
\hline D-1 anthesis (Figure 2.g) & Pedicellus & $\pm 1,7 \mathrm{~cm}$ \\
\cline { 2 - 3 } & Calyx & $\pm 2,5 \mathrm{~cm}$ \\
\cline { 2 - 3 } & Corolla & $\pm 3,7 \mathrm{~cm}$ \\
\cline { 2 - 3 } & Androecium & \\
& 1 pair of upper stamens & $\pm 2,8 \mathrm{~cm}$ \\
& 1 pair of lower stamens & $\pm 2,5 \mathrm{~cm}$ \\
\cline { 2 - 3 } & Staminode & $\pm 0,5 \mathrm{~cm}$ \\
\cline { 2 - 3 } & Gynoecium & $\pm 3,5 \mathrm{~cm}$ \\
\hline D anthesis (Figure 2.h) & Pedicellus & $\pm 1,8 \mathrm{~cm}$ \\
\cline { 2 - 3 } & Calyx & $\pm 2,8 \mathrm{~cm}$ \\
\cline { 2 - 3 } & Corolla & $\pm 5,5 \mathrm{~cm}$ \\
& Length & $\pm 4,5 \mathrm{~cm}$ \\
\hline & Width (corolla diameter) & $\pm 0,5 \mathrm{~cm}$ \\
\cline { 2 - 3 } & Androecium & \\
& 1 pair of upper stamens & $\pm 4,9 \mathrm{~cm}$ \\
& 1 pair of lower stamens & $\pm 4,5 \mathrm{~cm}$ \\
\cline { 2 - 3 } & Staminode & $\pm 5 \mathrm{~cm}$ \\
\cline { 2 - 3 } & Gynoecium & \\
\hline
\end{tabular}

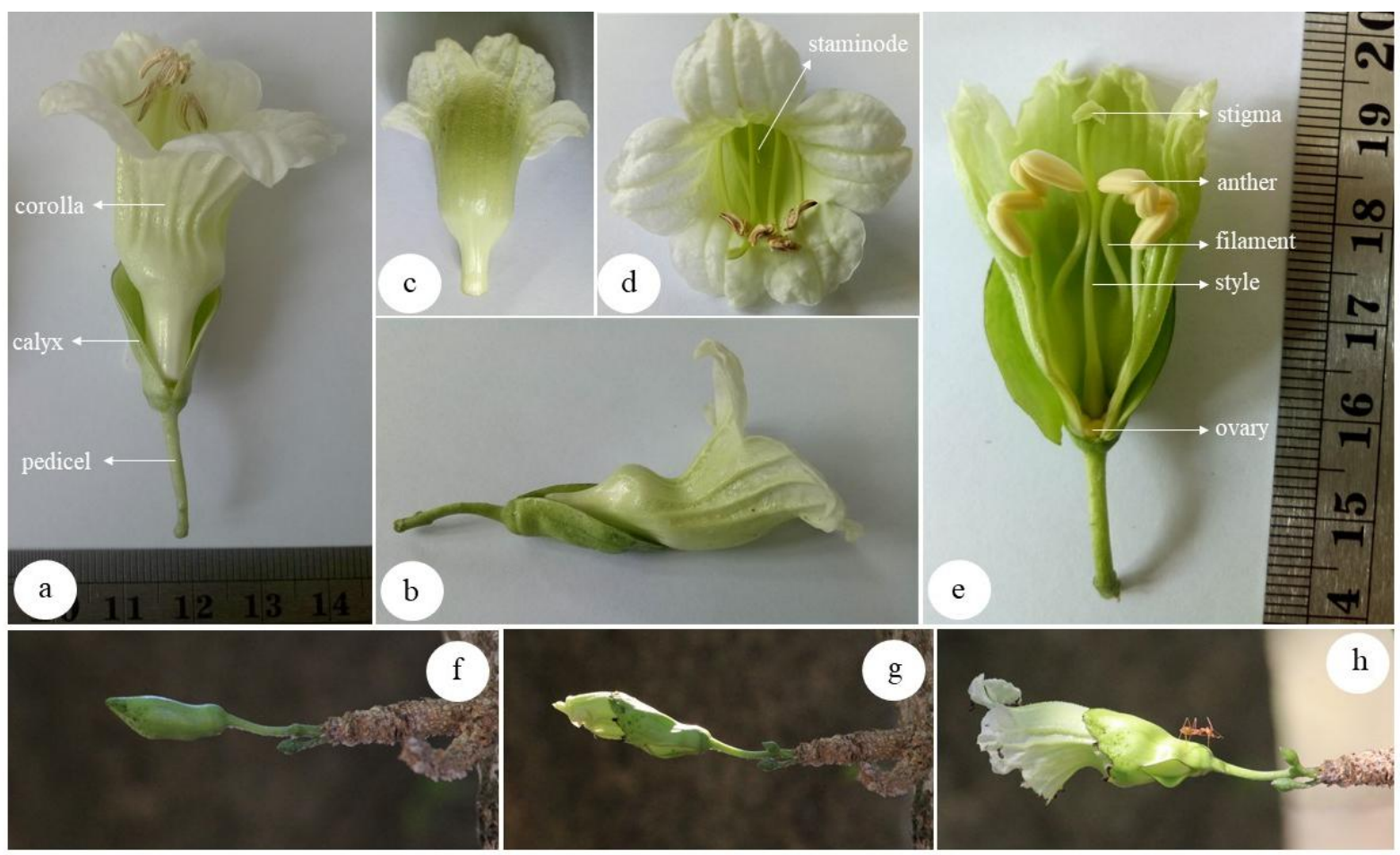

Figure 2. Floral morphology and development phase of P. cereifera. (a) flower on anthesis stage; (b) side view; (c) back view; (d) upside view; (e) generative organs; (f) flower at D-2 anthesis; (g) flower at D-1 anthesis; (h) flower at D anthesis

The observation results showed a relatively short flowering stage development on $P$. cereifera. The process from bud stage (D-2 anthesis) until D anthesis only required 3 days. The calyx still cover all parts of the flower at D-2 anthesis, with a bud length of about $2 \mathrm{~cm}$ (Fig. 2.f). After one day (D-1 anthesis), the calyx cleaved on one side and the corolla appear to pop up with the condition still closed (Fig. 2.g). In the morning, flower have opened (Fig. 2.h). The blooming flowers were predicted occurs during the night. This condition indicated that the $P$. cereifera including nocturnal flowering plant. This was also supported by the morphological characters of the corollas which were pale in color (not brightly coloured), large mouthed, stiff and had a little pungent odour. Corolla of $P$. cereifera opened in a short time. The corollas began to fall at the morning 
or midday. Flowers in many species of nocturnal pollination have a life cycle of several days. This nocturnal pollination strategy ensures seed set when pollinators are scarce or unpredictable (Shivanna \& Tandon 2014). But this strategy does not apply to $P$. cereifera because the flowers bloom lasts only half of day. This condition has the potential to be a limiting factor in reproductive biology of the species.

Although the calyx and corolla do not directly contribute to the development of fruits and seeds, the end result of reproduction, they do promote reproduction events. The calyx is thought to be an organ that aids in the defense of the flower bud. In some insects, it serves as an advertising organ for pollinators. Others, however, are persistent, remaining fresh and green before fruit maturity, and supplying photosynthates to the developing fruit (Shivanna \& Tandon 2014).

\section{b. Pollen viability and stigma receptivity}

One of the simple methods used in earlier studies to assess pollen viability has been the tetrazolium test (TTC). The test with TTC indicated the presence of dehydrogenase enzymes in the pollen of $P$. cereifera by showed of the dark red coloration of pollen (Fig. 3.a). The pollen grains that were not colored were considered unviable (Fig. 3.b). When pollen grains are suspended in a solution of colorless soluble tetrazolium salt, pollen dehydrogenases, if present, convert the colorless soluble tetrazolium salt to a reddish insoluble material known as formazan. Formazan accumulates in the pollen cytoplasm and gives pollen a reddish color. In this study, $P$. cereifera pollen had a high viability at the D-1 anthesis stage and declines as the flower ages at the D anthesis stage. At the D-1 anthesis, although the anther not yet cracking, mostly pollen grains were viable, with a percentage of $>90 \%$ (Fig. 4), but at the D anthesis, the amount of viable pollen grains were less than $50 \%$. The results indicated that a small potential of pollination because the pollen were highly viable when the corolla still closed. Compared to other Bignoniaceae species, for example in Tabebuia pallida, $100 \%$ of the pollens had already been viable at $\mathrm{D}$ anthesis, when the flowers have bloomed (Damaiyani \& Prabowo 2021).
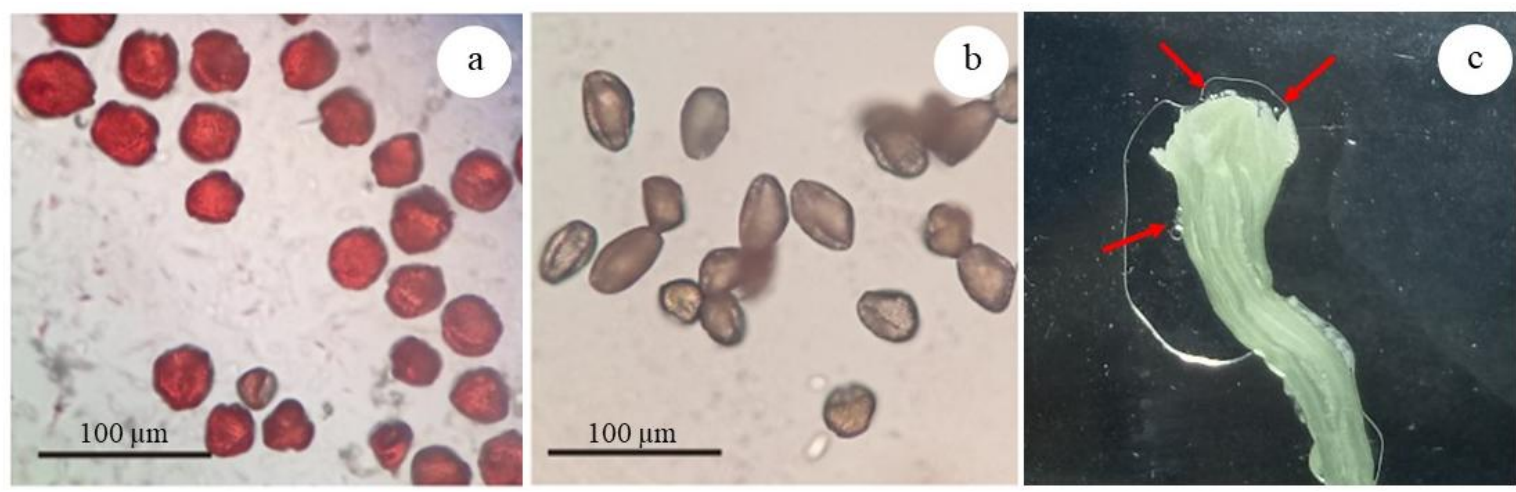

Figure 3. Pollen viability and stigma receptivity. (a) Pollen of the P. cereifera stained with TTC, viable (red), (b) unviable (not stained), (c) receptive stigma at D-1 anthesis stage

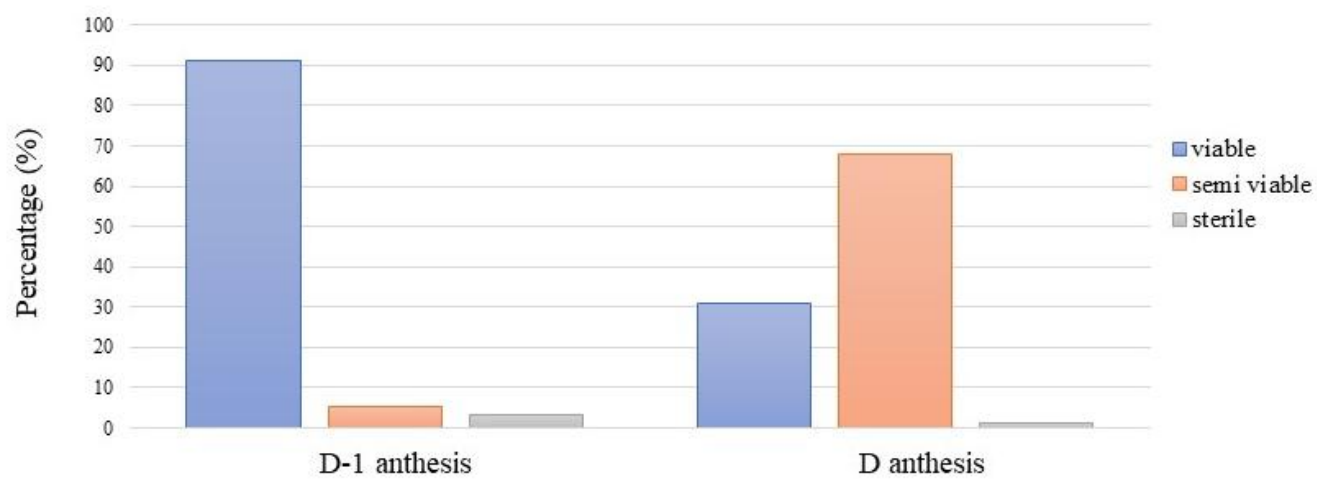

Phase

Figure 4. The percentage pollen viability of $P$. cereifera at D-1 anthesis and D anthesis

Stigma receptivity is an important stage in flower maturation that have a major impact on pollination success at different stages of the flower's life cycle. The stigma is the localized part of the pistil and pollen grains are trapped on the stigmatic surface during pollination. Receptivity of the stigma is a critical factor for successful completion after the post-pollination events. Stigma receptivity confers the ability of the stigma to support germination and tube growth of viable pollen (Biswas 2017). The receptive surface of the stigma contains extracellular proteins either as an extracuticular layer called pellicle in dry stigma or as a component of 
the exudates in wet stigma. Esterase and peroxidase are the important components of the stigma surface proteins and their presence is related to stigma receptivity. In general, receptivity peaks shortly after anthesis, but this varies by species and is influenced by temperature and humidity (Dey et al. 2016). The test using hydrogen peroxide $\left(\mathrm{H}_{2} \mathrm{O}_{2}\right)$ showed that stigma $P$. cereifera at D-1 anthesis had been receptive, while at the $\mathrm{D}$ anthesis was no longer receptive. It was estimated that stigma receptive only lasts overnight, more detailed research is needed to find out how many hours the receptivity of the stigma. Air bubbles were found on the surface of stigma at the D-1 anthesis after being dropped by $\mathrm{H}_{2} \mathrm{O}_{2}$ (Fig. 3.c). The formation of air bubbles on the stigma tested by $\mathrm{H}_{2} \mathrm{O}_{2}$, which acts as a substrate for enzyme, showed peroxide enzyme activity on the surface of the stigma (Shivanna \& Tandon 2014).

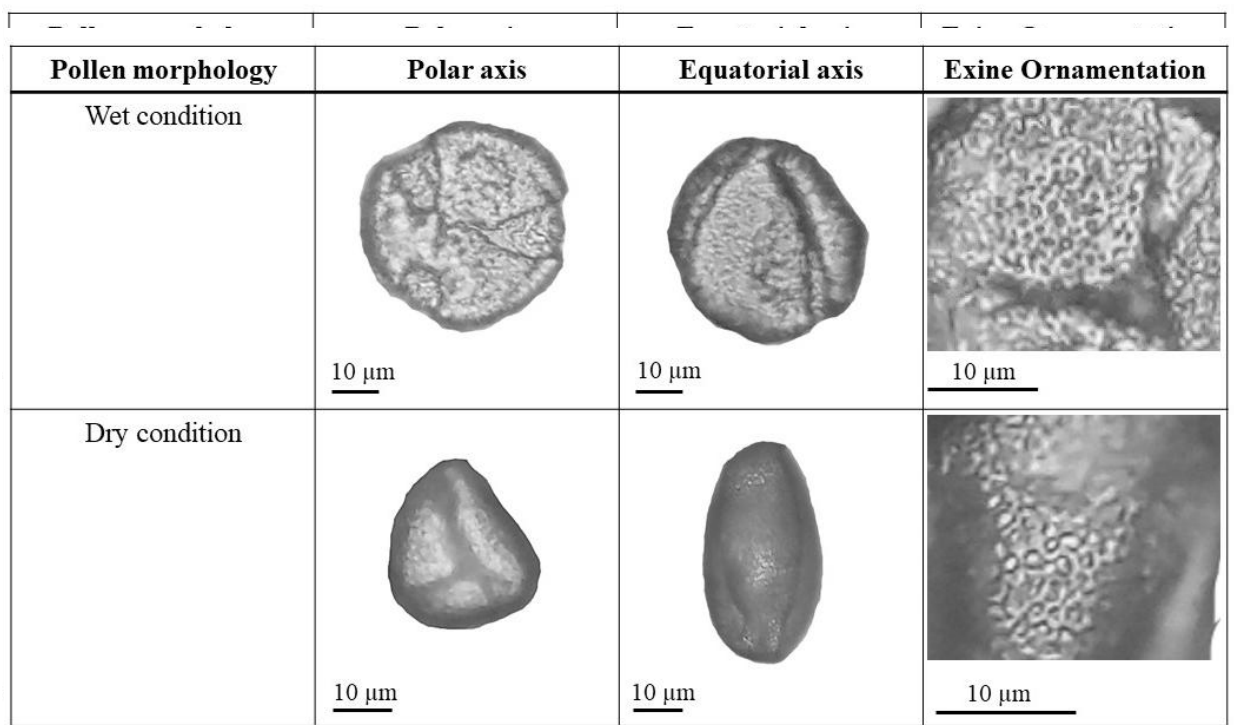

Figure 5. Pollen morphology of $P$. cereifera in wet dan dry condition

Table 3. Outcrossing index of $P$. cereifera

\begin{tabular}{|c|c|c|c|}
\hline Characteristics & value & $\begin{array}{l}\text { Outcrossing index } \\
(\mathrm{OCI})\end{array}$ & Breeding systems \\
\hline Flower diameter & $\pm 4,5 \mathrm{~cm},>6 \mathrm{~mm}=3$ & \multirow[t]{3}{*}{4} & \multirow{3}{*}{$\begin{array}{l}\text { Outcrossing, partially } \\
\text { self-compatible, } \\
\text { pollinators required }\end{array}$} \\
\hline $\begin{array}{l}\text { Temporal separation of stigma receptivity } \\
\text { and anther dehiscence }\end{array}$ & $\begin{array}{l}\text { Stigma and anther matured at the } \\
\text { same time }=0\end{array}$ & & \\
\hline $\begin{array}{l}\text { Spatial position between anthers and } \\
\text { stigma }\end{array}$ & $\begin{array}{l}\text { stigma was positioned higher than } \\
\text { stamen }=1\end{array}$ & & \\
\hline
\end{tabular}

The observation pollen morphology of $P$. cereifera under light microscopy (LM) with 40 x 10 magnification showed in the Figure 5. The dispersal unit of pollen was monad. Monad meaned the dispersal unit of pollens consisting of one unit pollen grain. In a dry condition, the length of the polar axis varied from $39,24 \mu \mathrm{m}-47,35$ $\mu \mathrm{m}$ and the equatorial diameter varied from $22,34 \mu \mathrm{m}$ $29,55 \mu \mathrm{m}$. It categorized into medium size $(25-50 \mu \mathrm{m})$ (Hesse et al. 2009). The morphology of a pollen grains were measured by the ratio of the length of the polar axis to the equatorial diameter $(\mathrm{P} / \mathrm{E})$. It showed that the shapes of pollen grains were prolate with $\mathrm{P} / \mathrm{E}$ Index $=$ 1,67. In apertural types, the investigated pollens was tricolpate. Tricolpate meaned a pollen with 3 elongated apertures (Fig. 5). Pollen shape and aperture location directly related to pollen polarity, which was determined

\section{Pollen morphology}

In reproductive ecology, pollen morphology's function is limited to describing pollen grains of the focal species and identifying conspesific and heterospesific pollen loads on the floral visitor and the stigma (Shivanna \& Tandon 2014). From another point of view, a number of studies exist describe different kinds of pollinators influenced pollen morphology (Stroo 2000). Therefore by characterizing the morphology of pollen, the pollinating agent can be estimated. The softer ornamentations on pollen reflected abiotic pollination (anemophily). For biotic pollination (zoophily) several authors found rough surface of the pollens. The sample contained a wide variety of ornamentation types including striate, foveolate, reticulate, verrucate, gemmate and echinate (Stroo 2000). 
(D-1 anthesis), resulting in a score of 0 , and the stigma and anthers were spatially isolated, resulting in a score of 1. As a result, the total OCI value was 4 . According to Dafni (1992), breeding systems are outcrossing, partially self-compatible, and require pollinators.

Pollinators are needed to promote successful pollination of $P$. cereifera, according to the OCI value. Bignoniaceae species have been confirmed to be pollinated by bats, one of which is $P$. cereifera (Stroo 2000). P. cereifera's floral biology accommodates bat pollinators by being open at night, wide in size (1 to 3,5 inches), and pale in color. According to Ratto et al. (2018), chiropterophilous plants are more advanced than other zoophilous plants, with lower reproductive success when bats are removed from the flower for bat-pollinated plants compared to plants pollinated by birds or rodents. However, bat populations are seriously endangered in many parts of the world, with 80 percent of bat species necessitating research or conservation efforts.This condition could potentially be a limiting factor in a succesful reproductive biology of $P$. cereifera, compounded with the conditions of pollen grains with a relatively short viability time.

In management of plant collection at botanic garden, the limiting factors in a succesful reproductive biology of the species must be considered. A solution is needed to reduce the inhibiting factor. Therefore, to support the success of conservation programs especially for threatened collections such as $P$. cereifera, it is necessary to create ecosystem services for the pollinators. In this case, it is possible by fulfilling the living needs of pollinator by providing the other nocturnal flowering plant around the threatened collection as an attractant and source of food and energy for pollinator.

In conclusion, $P$. cereifera flower was monoecious, had morphological character that supported nocturnal pollination. Stigma and anthers spatially separated, but there was no temporal separation of stigma receptivity and anther dehiscence. Based on the flower biology, the pollen ornamentation (reticulate type), and the OutCrossing Index $(\mathrm{OCI}=4)$, the breeding system was outcrossing but partially self-compatible, required pollinators (zoophily).

\section{Acknowledgement}

The researcher would like to express gratitude to the Head of the Research Center for Plant Conservation and Botanic Garden - Indonesian Institute of Sciences for the research permit, the Registration Unit of Purwodadi Botanic Garden for the information about $P$. cereifera collection.

\section{References}

Al-Hawshabi OSS, El-Naggar SMI, Dahmash ABA. 2017. Addition of some Angiospermic plants to the flora of Yemen. Kuwait Journal of Science 44 (2): 105-111.

Barrios B, Koptur S. 2011. Floral biology and breeding system of Angadenia berteroi (Apocynaceae): why do flowers of the pineland golden trumpet produce few fruits?. International
Journal of Plant Sciences 172(3): 378-385. DOI: 10.1086/658153.

Barros MG. 2001. Pollination ecology of Tabebuia aurea (Manso) Benth. \& Hook. and T. ochracea (Cham.) Standl. (Bignoniaceae) in Central Brazil cerrado vegetation. Revta brasil Bot 24(3): 255-261.

Barrows EM. 1977. Floral maturation and insect visitors of Pachyptera hymenaea (Bignoniaceae). Biotropica 9: 133-134.

Bertin RI. 1982. Floral biology, hummingbird pollination and fruit production of trumpet creeper Campsis radicans (Bignoniaceae). American Journal of Botany 69: 123134.

Bertin RI. 1985. Nonrandom fruit production in Campsis radicans: between year consistency and effects of prior pollinations. American Naturalist 126: 750-759.

Biswas P. 2017. Stigma receptivity of Corchorus aestuans L. with reference to in vivo pollen germination and peroxidase activity. Bioscience Discovery 8(3): 628-632.

Borrero JIH. 1972. Explotacion de las flores de Guayacan (Tabebuia chrysantha) por varias especies de aves e insetos. Biotropica 4 : 17-27.

Chauhan S, Shakya A. 2014. Flower biology and compatibility system of Campsis grandiflora (Bignoniaceae) in Uttar Pradesh India. The International Journal of Plant Reproductive Biology 6(1): 61-74.

Dafni A. 1992. Pollination Ecology: A Practical Approach, volume 46, pp. 250-478. Oxford University Press: Oxford, UK.

Damaiyani J, Prabowo H. 2021. Reproductive biology of Tabebuia pallida (Lindl.) Miers. (Bignoniaceae) collection of Purwodadi Botani. IOP Conf. Series: Earth and Environmental Science 743 (2021) 012047. doi:10.1088/1755-1315/743/1/012047

Demir G, Turgutoglu E, Kurt S. 2015. Assessment of pollen viability and germination in seven varieties of lemon. Journal of Crop Breeding and Genetics 1(1): 47-49.

Dey K, Mondal S, Mandal S. 2016. Studies on stigma receptivity of Grewia asiatica L. with reference to esterase and peroxidase activity. International Journal of Engineering Research \& Science 2(1):120-123.

Dhouibi R, Oueslati H, Bahri S, Jabou K, Bahri S. 2021. Chemical composition of germinating Tunisian almond (Prunus Amygdalus Mill.) seedlings oil. Kuwait Journal of Science 48 (2) : $1-12$.

Gan X, Cao L, Zhang X, Li H. 2013. Floral biology, breeding system and pollination ecology of an endangered tree Tetracentron sinense Oliv. (Trochodendraceae). Botanical Studies 54:50.

Gibbs PE, Bianchi M. 1993. Post-pollination events in species of Chorisia (Bombacaceae) and Tabebuia (Bignoniaceae) with late acting self-incompatibility. Botanica Acta 106: 64-71.

Gobatto-Rodrigues AA, Stort MNS. 1992. Biologia floral e reprodução de Pyrostegia venusta (KerGrawl) Miers Bignoniaceae. Revista Brasileira de Botânica 15: 1012-1031.

Halbritter H, Ulrich S, Grímsson F, Weber M, Zetter R, Hesse M, Buchner R, Svojtka M, Frosch-Radivo A. 2018. Illustrated Pollen Terminology, $2^{\text {nd }}$ edition, pp: 37-63. Springer International Publishing AG, Switzerland.

Hesse M, Halbritter H, Zetter R, Weber M, Buchner R, Frosch-Radivo A, Ulrich S. 2009. Pollen Terminology: An Illustrated Handbook. Springer -Verlag Wien, Austria.

Hao J, Pan L, Jia H, Jiang Q, Pan Q, Pinyopusarerk K, Kalinganire A. 2019. Floral structure and breeding systems of Manglietia conifera Dandy (Magnoliaceae). Forests 10(9): 756.

Kapp RO. 1969. Pollen and Spores. Brown Company Publishers, Lowa.

Linares LJ, Koptur S. 2010. Floral biology and breeding system of the crenulate leadplant, Amorpha herbacea var. crenulata, an endangered South Florida pine rockland endemic. Natural Areas Journal 30(2): 138-147. DOI: http://dx.doi.org/10.3375/043.030.0202.

Makwana MA, Akarsh P. 2017. Stigma receptivity test in diverse species of tomato International. Journal of Agricultural Science and Research 7(5): 1-8.

Navarro L, Guitián J. 2002. The role of floral biology and breeding system on the reproductive success of the narrow endemic Petrocoptis viscosa rothm. (Caryophyllaceae). Biological Conservation 103(2): 125-132. doi:10.1016/s00063207(01)00108-2

Rathod V, Behera TK, Munshi AD, Durgesh K, Jat GS, Krishnan GB, Sharma N. 2018. Pollen viability and in vitro pollen germination studies in Momordica species and their intra and 
interspecific hybrids. International Journal of Chemical Studies 6(6): 32-40.

Reyad-ul-Ferdous M , Rashid RB, Sikder MAA , Fahima Aktar F, Rashid MA. 2012. Preliminary in vitro biological and phytochemical screenings of Parmentiera cereifera Seem. Bangladesh Pharmaceutical Journal 15(2): 103-106.

Reyad-ul-Ferdous M, Pandaya S, Pandey M, parvez S, Mahamud K, Ayshi SS, Barman DB, Jahan N. 2015. Potential ex-vivo antimicrobial evaluation of barks of Parmentiera cereifera Seem. World Journal of Pharmaceutical Research 4(1):386390.

Shivanna KR, Tandon R. 2014. Reproductive Ecology of Flowering Plants: A Manual. Springer New, Delhi.

Soares TL, de Souza EH, de Carvalho Costa MAP, de Oliveira e Silva S, dos Santos-Serejo JA. 2016. Viability of pollen grains of tetraploid banana. Bragantia 75(2): 145-151. Doi: http://dx.doi.org/10.1590/1678-4499.328.

Souza CV, Nepi M, Machado SR, Guimarães E. 2017. Floral biology, nectar secretion pattern and fruit set of a threatened Bignoniaceae tree from Brazilian tropical forest. Flora 227: 46-55. doi:10.1016/j.flora.2016.12.007

Stroo A. 2000. Pollen morphological evolution in bat pollinated plants. $\quad P l \quad$ Syst Evol 222: 225-242. https://doi.org/10.1007/BF00984104

Sulusoglu M, Cavusoglu A. 2014. In vitro pollen viability and pollen germination in cherry laurel (Prunus laurocerasus L.). The Scientific World Journal ID657123 1-7 Doi:10.1155/2014/657123.

Vieira MF, Meira RMSA, Queiroz LP, Meira Neto JAA. 1992. Polinização e reprodução de Jacaranda caroba (Vell.) D.C. (Bignoniaceae) em áreas de cerrado do sudoeste brasileiro. Anais do $8^{\circ}$ Congresso da SBSP São Paulo, Brasil. 